\title{
PROSES PENGAMBILAN KEPUTUSAN UNTUK MEMAKAI CADAR PADA MUSLIMAH
}

\author{
Fitriani \\ Yulianti Dwi Astuti \\ Fakultas Psikologi dan Ilmu Sosial Budaya Universitas Islam Indonesia \\ Email: yulianti_da@yahoo.co.id
}

\begin{abstract}
This study aims to find out and understanding the decision making process on moslem women wearing the face veil (niqaab) and the factors influences moslem women wearing the face veil. The theory used in this study based on the decision making process theory which proposed by Gitosudarmo and Sudita (1997). Total respondents in this study are two moslem women in the aged of 20 to 25 years old, unmarried, wearing the face veil for at least one year, and the first time using the face veil is when still registered as an active student at a particular university in Yogyakarta. The data collection methods used in this study were interviews using an interview guide during the interview process. This study found that the two respondents had been going through the decision making process that similar to the theory propounded by Gitosudarmo and Sudita (1997) which includes setting the goals, identifying problems, developing various solutions alternative, evaluation on various solutions alternative that have been developed and choose an alternative that has been evaluated, implementing the decisions, evaluation upon the implemented decision, monitoring and perform corrective action. Despite all two respondents had known the consequences (risk) that will be encountered, both respondents continue to implement the decision because of the higher achievement or expectations, i.e. preserve their modesty, minimizing the possibility of individuals to cause other people immoral behavior, wanted to became a better person, expect Allah's blessings and to be put in paradise with variety of pleasures in it and so on. Sometimes, the decision was also implemented to avoid something worse that might happen later in the future which is severe consequences (risk) in the hereafter (aakhirah).
\end{abstract}

Keywords: decision making process, face veil (niqaab)

Pakaian merupakan salah satu dari sekian banyak nikmat Allah Subhaanahu wa Ta'aala yang wajib dipuji dan disyukuri oleh setiap manusia. Dengan adanya pakaian, manusia mendapatkan manfaat yang banyak yakni untuk menutupi aurat, melindungi tubuh dari terik panas ataupun dingin, serta memperindah penampilan seseorang. Dengan menyadari bahwa pakaian merupakan suatu nikmat, sudah sewajarnya manusia memuji Allah SWT dan mensyukuri nikmat yang telah diberikan tersebut. Salah satu bentuk dari syukur atas nikmat pakaian adalah dengan menjalankan hukum syari'at yang diperintahkan oleh Allah $S W T$ dan disampaikan oleh Nabi Muhammad $S A W$ terkait dengan pakaian.

Dalam Islam, wanita diperintahkan untuk ber-hijab. Dikemukakan oleh AlFauzan (2006) bahwa seorang wanita yang menutupi badannya dari (pandangan) laki-laki yang bukan mahram-nya disebut ber-hijab. Adapun hijab yang akan dibahas lebih lanjut oleh peneliti adalah cadar atau niqaab, yaitu kain penutup wajah atau sebagian dari wajah dengan hanya menampakkan kedua mata. Pengambilan keputusan untuk memakai cadar itu sendiri dianggap sebagai suatu pilihan dan kebebasan individu sehingga wanita yang memakai cadar memiliki hak untuk tetap memakai cadarnya tanpa ada yang melarang atau 
menentangnya. Meskipun pengambilan keputusan untuk memakai cadar dianggap sebagai suatu pilihan dan kebebasan individu, beberapa muslimah yang telah mengambil keputusan untuk memakai cadar seringkali tidak luput dari berbagai hinaan, penolakan dan pelarangan atau anti-cadar yang terjadi di beberapa negara, termasuk di Indonesia.

Ada sebagian masyarakat Indonesia yang menerima muslimah pengguna cadar, ada yang bersikap netral, serta ada pula yang menolak, melarang, hingga menghina muslimah yang memakai cadar karena dianggap sebagai sesuatu yang aneh, asing dan berlebih-lebihan. Bahkan, pada sebagian masyarakat mulai berkembang prasangka negatif bahwa setiap muslimah yang memakai cadar terkait dengan aliran sesat tertentu serta prasangka negatif bahwa setiap muslimah yang memakai cadar terkait dengan terorisme. Prasangka negatif yang ditujukan pada setiap muslimah yang memakai cadar tersebut semakin merebak semenjak media menyorot aksi teror yang dilakukan segelintir orang dengan mengatasnamakan Islam dan jihad. Dalam setiap pemberitaan, diperlihatkan para istri pelaku teror bom tersebut memakai cadar. Sosok para istri dari pelaku bom bunuh diri yang sering ditampilkan di media tersebut kemudian digeneralisasikan oleh sebagian besar masyarakat dengan setiap muslimah yang memakai cadar disebabkan penampilan luar yang sama, yaitu memakai cadar. Selain prasangka negatif, sebagian dari muslimah yang memakai cadar juga mendapatkan kendala berupa penolakan dan larangan memakai cadar dari pihak keluarga maupun dari peraturan yang diterapkan di beberapa fakultas dari perguruan tinggi-perguruan tinggi tertentu, baik yang tertulis maupun tidak.

Pengambilan keputusan untuk memakai cadar bukanlah suatu hal yang mudah dan terkadang memerlukan proses dengan waktu yang tidak sebentar. Hal itu dikarenakan sebelum melakukan pengambilan keputusan untuk memakai cadar, seorang muslimah perlu mempertimbangkan konsekuensikonsekuensi yang akan dihadapi beserta solusinya. Tujuan penelitian ini adalah untuk mengetahui dan memahami proses pengambilan keputusan untuk memakai cadar pada muslimah. Selain itu, penelitian ini juga ingin memahami lebih jauh mengenai faktor-faktor yang mempengaruhi muslimah untuk memakai cadar.

Dermawan (2006) mengemukakan bahwa manusia adalah pembuat keputusan (decision-making man), pengambil keputusan, penentu atas sebuah pilihan dari sejumlah pilihan. Pengambilan keputusan terjadi setiap saat sepanjang hidup manusia. Kehidupan manusia adalah kehidupan yang selalu diisi oleh peristiwa pengambilan keputusan. Pernyataan serupa dikemukakan oleh Suharnan (2005) bahwa setiap hari orang terlibat di dalam tindakan membuat keputusan atau decision making, bahkan mungkin harus dilakukan beberapa kali. Mulai dari masalah-masalah yang sederhana sampai dengan masalah-masalah yang kompleks dan menuntut pertimbangan banyak serta mendalam. Aktivitas pembuatan keputusan sering dilakukan orang baik disadari atau tidak disadari, sebab di dalam kehidupan sehari-hari seseorang akan banyak menemukan situasi yang tidak pasti(uncertainty).

Setiap keputusan mengandung konsekuensi-konsekuensi yang mungkin terjadi dan harus dihadapi. Hal itu sejalan dengan yang dikemukakan oleh Anderson (Suharnan, 2005) bahwa pembuat keputusan harus mempertimbangkan konsekuensi yang mungkin terjadi sebagai akibat keputusankeputusannya. Konsekuensi keputusan meliputi konsekuensi yang dapat terlihat langsung dan tidak langsung, jangka pendek dan jangka panjang, bagi diri sendiri dan orang lain, dan keuntungan dan kerugian yang mungkin akan didapatkan. Menilai keputusan yang terbaik adalah hal yang sulit. Karena, pengambilan keputusan dilakukan pada masa kini, sedang hasil terlihat pada masa depan. Dengan kata lain, keputusan yang diambil merupakan pilihan atas peristiwa yang diharapkan akan terjadi, dengan berdasarkan atas data masa lalu.

Menurut Gitosudarmo dan Sudita (1997), tiga faktor utama dalam pengambilan keputusan yaitu: 
1) Nilai individu pengambil keputusan. Nilai-nilai individu pengambil keputusan merupakan keyakinan dasar yang digunakan seseorang jika ia dihadapkan pada permasalahan dan harus mengambil suatu keputusan. Nilai-nilai ini telah tertanam sejak kecil melalui proses belajar dari lingkungan keluarga dan masyarakat.

2) Kepribadian. Keputusan yang diambil seseorang juga dipengaruhi oleh faktor psikologis seperti kepribadian. Dua variabel utama kepribadian yang berpengaruh terhadap keputusan yang dibuat, seperti idiologi versus kekuasaan dan emosional versus objektivitas.

3) Ideologi versus kekuasaan. Beberapa pengambil keputusan memiliki suatu orientasi ideologi tertentu, yang berarti keputusannya pada suatu perangkat prinsip tertentu. Sementara itu, pengambil keputusan atau orang lain mendasarkan keputusannya pada sesuatu yang secara politis akan meningkatkan kekuasaannya secara pribadi.

4) Emosional versus objektivitas. Beberapa pengambil keputusan kadang kala emosionalnya mempengaruhi keputusan yang diambilnya. Emosional tersebut dapat berupa kecenderungan kepribadian seseorang atau emosional yang berasal dari kebutuhan akan perlindungan. Emosional dapat mempengaruhi cara suatu permasalahan dianalisis, jenis informasi dan alternatif yang dipertimbangkan dalam proses pengambilan keputusan. Informasi yang objektif diabaikan, dan keputusan hanya didasarkan kepada perasaan saja. Sementara itu beberapa pengambil keputusan yang lain lebih objektif di mana mereka menghindari adanya kekeliruan persepsi tentang permasalahan maupun informasi yang berkaitan dengannya.

5) Kecenderungan dalam pengambilan resiko. Dalam mengambil suatu keputusan ada orang yang senang dengan resiko dan ada orang yang tidak senang dengan resiko, dan ada juga yang dikatakan netral terhadap resiko. Orang yang senang dengan resiko akan berbeda dalam mengevaluasi serangkaian alternatif maupun memilih suatu alternatif dengan mereka yang tidak senang dengan resiko. Dalam keputusan investasi misalnya, orang yang senang dengan resiko akan memilih alternatif investasi yang memberikan hasil besar sekalipun dengan resiko yang juga besar. Sementara ekstrim lain mereka yang takut akan resiko memilih alternatif investasi yang resiko kegagalannya rendah sekalipun hasilnya juga rendah.

Adapun terkait dengan prosesnya, Gitosudarmo dan Sudita (1997) menggambarkan proses pembuatan keputusan sebagai berikut: penetapan tujuan, mengidentifikasi permasalahan, mengembangkan berbagai alternatif solusi, melakukan evaluasi (penilaian) atas berbagai alternatif solusi yang telah dikembangkan dan memilih sebuah alternatif yang telah dievaluasi, melaksanakan keputusan, melakukan evaluasi (penilaian) atas keputusan yang dilaksanakan, mengendalikan dan melakukan tindakan korektif. Mengacu pada hal tersebut, proses pengambilan keputusan meliputi penetapan tujuan, mengidentifikasi permasalahan, mengembangkan berbagai alternatif solusi, mengevaluasi dan memilih sebuah alternatif, melaksanakan keputusan, kemudian mengevaluasi hasil dari keputusan yang telah diambil dan jika keputusan yang diambil dianggap kurang berhasil akan terjadi pengulangan proses pengambilan keputusan. Proses di atas ditunjukkan gambar berikut:

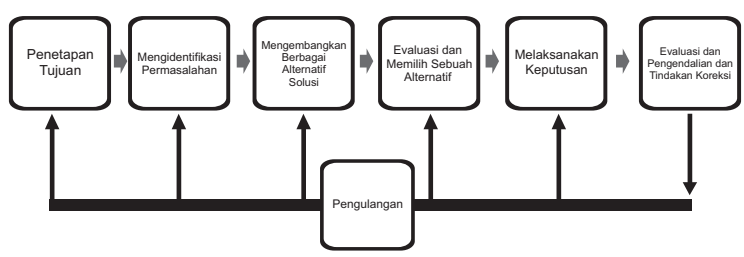

Gambar 1. Proses Pengambilan Keputusan. 
Berdasar penjelasan di atas, pertanyaan penelitian yang hendak diajukan adalah bagaimana proses pengambilan keputusan untuk memakai cadar pada muslimah?

\section{METODE PENELITIAN}

Fokus penelitian ini adalah proses pengambilan keputusan untuk memakai cadar pada muslimah. Responden penelitian ini adalah muslimah yang berusia antara 20 hingga 25 tahun, belum menikah, telah memakai cadar minimal satu tahun dan waktu pertama kali menggunakan cadar adalah ketika masih tercatat sebagai mahasiswi aktif pada perguruan tinggi tertentu di Yogyakarta.

Metode pengumpulan data dalam penelitian ini adalah wawancara dengan menggunakan interview guide selama proses wawancara berlangsung. Adapun jenis wawancara yang akan dilakukan peneliti adalah wawancara terbuka (Overt Interview). Wawancara dilakukan terhadap dua orang muslimah yang dipilih secara purposive dengan kriteria yang telah ditetapkan sebagaimana dijelaskan sebelumnya.

Adapun metode analisis data yang akan digunakan oleh peneliti adalah Metode Perbandingan Tetap (Constant Comparative Method). Dinamakan Metode Perbandingan Tetap atau Constant Comparative Method karena dalam analisis data, secara tetap membandingkan satu datum dengan datum yang lain, dan kemudian secara tetap membandingkan kategori dengan kategori lainnya. Secara umum proses analisis datanya mencakup: reduksi data, kategorisasi data, sintesisasi, dan diakhiri dengan menyusun hipotesis kerja.

\section{HASIL PENELITIAN DAN PEMBAHASAN}

Berdasarkan penelitian yang telah dilakukan, kedua responden sama-sama merasa terkejut karena tidak menyangka akan melihat muslimah yang memakai cadar ketika menghadiri kajian Islam untuk pertama kalinya. Meskipun terkejut, kedua responden sama-sama tidak merasa takut.
Responden I memilih untuk mengabaikan (tidak meninggalkan kajian Islam) meskipun menemukan hal yang tak terduga (melihat muslimah yang memakai cadar) karena sejak awal Responden I memiliki tujuan mencari ilmu agama yang murni untuk Allah tanpa adanya tendensi apapun. Adapun Responden II, meskipun sejak awal memiliki keinginan untuk memakai cadar, namun Responden II sempat merasa tidak nyaman ketika pertama kali melihat muslimah yang memakai cadar di tempat kajian Islam yang dihadiri karena khawatir tidak diterima dengan penampilannya yang berbeda dan merasa harus berbeda dalam bersikap dan bertutur kata. Selain itu, kedua responden juga memiliki rasa penasaran yang sama yaitu penasaran mengapa para muslimah memutuskan untuk memakai cadar. Rasa penasaran ini mendorong rasa ingin tahu dan membuat kedua responden mencari informasi di kemudian hari.

Faktor penghambat pertama dalam pengambilan keputusan untuk memakai cadar pada kedua responden adalah persepsi awal. Pada responden I, persepsi awal Responden I didasarkan pada informasi masa lalu yang tidak sesuai dengan nilai yang dianut. Pada awalnya, Responden I yang menyukai kebersihan dan kerapian belum merasa tertarik dan sama sekali tidak pernah membayangkan bahwa dirinya kelak akan melakukan pengambilan keputusan untuk memakai cadar karena muslimah yang pertama kali dilihat Responden I terlihat kurang rapi (pakaian tidak disetrika) dan terkesan kumuh. Sedangkan pada Responden II yang sebenarnya telah memiliki ketertarikan untuk memakai cadar meski belum mengetahui ilmu terkait cadar, persepsi awal Responden II didasarkan atas penilaian awal bahwa muslimah yang memakai cadar di tempat kajian Islam tersebut adalah ekstrim. Persepsi awal kedua responden yang menjadi penghambat pertama dalam pengambilan keputusan untuk memakai cadar kemudian berubah karena seringnya interaksi dengan muslimah yang memakai cadar di tempat kajian Islam yang dihadiri. Responden I melihat muslimah yang memakai cadar di tempat kajian ternyata rapi dan bersih, berbeda 
dengan informasi masa lalu yang dilihatnya. Adapun Responden II, meskipun pada awalnya Responden II menilai muslimah yang memakai cadar di tempat kajian Islam tersebut adalah ekstrim, Responden II mulai tertarik untuk menutup wajah seperti muslimah yang dilihatnya dengan memakai slayer.

Selain karena adanya perubahan persepi awal terkait cadar, yang menyebabkan kedua responden memutuskan untuk memakai cadar di kemudian hari adalah rasa malu yang hadir ketika harus berpapasan atau bertemu dengan laki-laki non-mahram. Rasa malu yang dimaksudkan di sini bukanlah rasa malu yang disebabkan oleh rasa tidak percaya diri namun rasa malu yang timbul sebagai hasil pengetahuan yang ada. Pengetahuan yang dimaksud adalah pengetahuan terkait batasan-batasan pergaulan antara seorang muslimah dengan laki-laki non-mahram seperti tidak saling menyentuh, tidak menyepi berdua-duaan (khalwat), menutup aurat, dan sebagainya. Hal itu sebagaimana yang dikemukakan oleh Al-Wadi'iyyah (2002) bahwa malu adalah sifat yang termasuk akhlak yang utama dan merupakan perhiasan manusia. Dengan hilangnya sifat malu, dilakukanlah setiap kejelekan sehingga tertumpahlah darah manusia, ternodailah kehormatan, mendengar kebenaran namun menolaknya dan dilaksanakanlah perbuatan keji, orang yang tua tidak dihormati, berbaurlah lakilaki dan perempuan, wanita keluar dengan menampakkan perhiasan dan dandanannya, serta bepergian tanpa mahram. Sifat malu menjadikan seseorang memiliki perasaan bahwa Allah Subhaanahu wa Ta'aala senantiasa mengawasinya, baik di tempat yang tersembunyi maupun yang terlihat, baik di waktu malam maupun siang. Meskipun demikian, ada pula sifat malu di antara para makhluk, sehingga seseorang meninggalkan kemaksiatan karena malu kepada manusia. Dikemukakan pula oleh Al-Wadi'iyyah (2002) bahwa sifat malu yang dipuji dan yang dimaksud dalam sabda Nabi Shallallahu 'alaihi wa Sallam adalah suatu perangai yang mendorong untuk melakukan perbuatan baik dan meninggalkan perbuatan yang jelek. Adapun kelemahan yang menjadikan orangnya mengurangi hak-hak Allah Subhaanahu wa Ta'aala atau hak-hak hamba-Nya, bukanlah sifat malu. Sebaliknya, itu merupakan kelemahan dan kerendahan.

Meskipun mengetahui bahwa ketika memutuskan untuk memakai cadar seorang muslimah tidak luput dari hinaan dan konsekuensi lainnya sebagai resiko dari pengambilan keputusan untuk memakai cadar, namun keinginan untuk memakai cadar pada kedua responden juga semakin kuat karena adanya keinginan untuk menjaga diri dan privacy yang tidak ingin diganggu oleh laki-laki non-mahram. Responden II merasa dengan memakai cadar maka dirinya sudah meminimalkan penyebab laki-laki non-mahram berkeinginan untuk melakukan perbuatan maksiat dan merasa dengan memakai cadar dapat menjaga dirinya dari berbagai gangguan yang tak diinginkan. Sejalan dengan Responden II, Responden I meyakini bahwa dengan memakai hijab, seorang muslimah akan mudah dikenal meskipun tertutup seluruh tubuhnya. Yang dimaksud dengan mudah dikenal yaitu hijab yang dikenakan oleh muslimah tersebut dapat menjadi tanda yang akan membuat orang-orang yang berada di sekitarnya mengenal, menyadari dan mengetahui bahwa hijab tersebut merupakan simbol (pertanda) wanita baik-baik sehingga tidak berani atau tidak berkeinginan untuk mengganggu.

Meskipun kedua responden memakai cadar atas dasar keinginan sendiri (bukan karena dipaksa atau diperintahkan oleh orang lain), namun terdapat perbedaan pengambilan keputusan untuk memakai cadar. Adapun usaha yang dilakukan oleh kedua responden setelah memakai cadar agar pengambilan keputusan untuk memakai cadar dapat diterima meskipun tidak diijinkan pada awalnya oleh keluarga terutama orangtua adalah dengan menjalin komunikasi. Terkadang ketidaksetujuan pihak keluarga terhadap cadar dikarenakan cadar mendapatkan image yang buruk dari media ataupun dari lingkungan sekitar. Sebenarnya cadar merupakan hijab bagi muslimah namun karena penggambaran media yang menampilkan istri-istri para 
teroris dalam peristiwa bom di Indonesia, cadar kini mendapatkan stigma yang buruk. Selain itu, ketidaksetujuan keluarga juga bisa dikarenakan tempat tinggal yang berbeda menyebabkan kurangnya komunikasi yang menyebabkan orangtua tidak mengetahui seperti apa ta'lim yang seperti diikuti oleh sang anak. Dalam keadaan ini, sang anak yang mungkin pulang dalam keadaan berubah drastis tentu akan membuat kaget keluarga. Oleh karena itu, kedua responden berusaha tetap menjalin komunikasi yang baik dengan keluarga serta berusaha meluruskan pendapat atau persangkaan keluarga yang salah berkenaan dengan cadar melalui diskusi atau obrolan-obrolan ringan ketika berkumpul bersama. Kedua responden ingin menunjukkan dan menjelaskan bahwa meskipun memilih untuk memakai cadar, namun keduanya berbeda dengan aliran sesat yang tidak mau dicuci atau diangkat pakaiannya atau bahkan menganggap najis orang lain serta menjelaskan bahwa dirinya memilliki pemahaman yang berbeda dengan pemahaman para teroris. Kedua responden mau bergaul dengan lingkungan sekitar sebagaimana biasanya sesuai adab-adab pergaulan yang baik dalam Islam. Responden I bahkan berusaha untuk tetap berbuat baik kepada orangtua dengan taat dan patuh selama orangtua tidak memerintahkan pada hal yang menyelisihi syari'at dan membuktikan kepada orangtua bahwa dirinya tetap bisa bekerja sebagai guru di sekolah meskipun belum lulus kuliah dan telah memutuskan untuk memakai cadar ketika keluar rumah ataupun berpapasan dengan laki-laki non-mahram.

\section{SIMPULAN DAN SARAN \\ Simpulan}

Berdasarkan hasil penelitian, diketahui bahwa proses pengambilan keputusan yag dikembangkan responden meliputi penetapan tujuan, mengidentifikasi permasalahan, mengembangkan berbagai alternatif solusi, melakukan evaluasi (penilaian) atas berbagai alternatif solusi yang telah dikembangkan dan memilih sebuah alternatif yang telah dievaluasi, melaksanakan keputusan, melakukan evaluasi (penilaian) atas keputusan yang dilaksanakan, monitoring dan melakukan tindakan korektif.

Meskipun kedua responden memakai cadar atas dasar keinginan sendiri, namun terdapat perbedaan pengambilan keputusan untuk memakai cadar. Responden I tidak mau terburu-buru dalam melakukan pengambilan keputusan untuk memakai cadar meskipun teman-teman sebaya yang sejak awal belajar di tempat kajian yang sama sudah melakukan pengambilan keputusan untuk memakai cadar terlebih dahulu. Responden I merasa belum siap untuk ilmu dan juga resiko yang mungkin akan dihadapi dari pihak keluarga terutama orangtua. Namun setelah memiliki kesiapan baik ilmu maupun kemantapan hati, Responden I memutuskan untuk memakai cadar dan tidak merasa khawatir dengan cemoohan dan hinaan yang akan ditujukan karena yakin bahwa segala konsekuensi yang berkaitan dengan perkara dunia akan sirna jika diiringi dengan akhlak dan adab yang baik terhadap sesama. Oleh karena itu, ketika Responden I mendapatkan hinaan ketika berada di jalan, responden yang sudah tahu bahwa hal tersebut akan terjadi lebih memilih untuk tersenyum dan bersikap biasa serta berusaha sebisanya untuk menyapa terlebih dahulu. Responden I juga berusaha terus memantapkan keputusan yang telah diambil dengan mengikuti kajian Islam dan berkumpul dengan teman-teman yang sejalan yang bisa mengingatkan, menasihati dan memberikan semangat meskipun temanteman tersebut tidak memakai cadar. Oleh karena itu, meskipun Responden I termasuk pribadi yang tidak suka tergesa-gesa dalam melakukan pengambilan keputusan, lebih cenderung untuk berhati-hati sebelum melakukan suatu tindakan dan berusaha mencari ilmu terlebih dahulu sebelum melaksanakan, namun Responden I akan teguh, kuat dan kokoh ketika pengambilan keputusan untuk memakai cadar telah dilaksanakan karena sudah tahu langkah apa saja yang dapat ditempuh untuk mengatasi masalah yang dihadapi sebagaimana yang telah diperkirakan sebelumnya.

Berbeda dengan Responden I, Responden II segera memakai cadar ketika 
merasa memiliki keinginan yang begitu kuat untuk memakai cadar di bulan Ramadhan meskipun di lingkungan tempat tinggal Responden II tidak ada yang memakai cadar. Responden bahkan sempat merasa down ketika teman-teman mempertanyakan kemantapan hatinya yang tiba-tiba memutuskan untuk memakai cadar dengan nada mengejek. Responden II juga pernah berpikir untuk melepaskan cadar yang dikenakannya dan mempertanyakan dalam hati untuk apa mengenakan cadar karena ulama pun ada yang berpendapat bahwa cadar bukanlah kewajiban. Hal ini disebabkan Responden II merupakan satusatunya muslimah yang memutuskan untuk memakai cadar di tempat tinggalnya dan berani untuk segera mengambil suatu keputusan yang mengandung resiko ataupun penuh tantangan yaitu melaksanakan pengambilan keputusan untuk memakai cadar tanpa adanya persiapan jangka panjang terkait langkah-langkah apa saja yang perlu diambil atau dilakukan jika terjadi suatu hal yang tak diinginkan ketika keputusan untuk memakai cadar telah dilaksanakan kelak. Oleh karena itu, ketika keinginan untuk melepaskan cadar muncul, Responden II berusaha melupakannya dengan tidur. Usaha lain yang dilakukan Responden II adalah dengan mengikuti kajian Islam dan berkumpul dengan muslimah lainnya yang juga memakai cadar untuk menguatkan keputusan yang telah diambil (komitmen).

Pada kedua responden ditemukan bahwa meskipun responden telah mengetahui konsekuensi (resiko) yang akan dihadapi, kedua responden tetap melaksanakan keputusan karena adanya pencapaian yang lebih tinggi yang hendak dituju ataupun adanya harapan-harapan yang hendak dipenuhi, misal: ingin lebih terjaga, ingin meminimalkan kemungkinan individu menjadi penyebab orang lain berbuat maksiat, ingin menjadi pribadi yang lebih baik, mengharap ridho Allah dan berharap akan dimasukkan ke dalam surga dengan berbagai kenikmatannya, dan sebagainya. Terkadang, keputusan juga dilaksanakan untuk menghindari sesuatu yang lebih buruk yang mungkin akan terjadi di kemudian hari jika tidak dilaksanakan, yaitu konsekuensi (resiko) yang lebih berat di akhirat.

\section{Saran}

Mengacu pada uraian tersebut, peneliti menyampaikan rekomendasi sebagai berikut:

1) Bagi Muslimah

Bagi muslimah yang memiliki keinginan untuk memakai cadar hendaknya mempelajari dan memahami ilmunya terlebih dahulu serta menyampaikannya melalui lisan, tulisan maupun akhlak dan adab yang baik, santun dan tepat serta dilakukan dengan cara yang hikmah kepada orangtua dan masyarakat di sekitarnya sehingga pengambilan keputusan yang akan dipilih tidak memicu terjadinya hal-hal yang tidak diinginkan serta dapat meminimalkan terjadinya resiko dan menghindari prasangka yang mungkin akan ditujukan.

Selain itu, dengan memahami ilmunya terlebih dahulu akan membantu memantapkan dan menenangkan hati disebabkan suatu pengambilan keputusan dengan kondisi kepastian di mana pengambil keputusan memiliki informasi yang lengkap mengenai keputusan yang akan diambilnya, termasuk di dalamnya adalah mengetahui masalah, kendala, serta konsekuensi yang mungkin akan dihadapi dapat mengantisipasi terjadinya hal-hal yang merugikan serta dapat membantu menemukan jalan keluar yang terbaik dari berbagai alternatif yang telah ada.

Bagi muslimah yang telah mengambil keputusan untuk memakai cadar hendaklah bersabar atas setiap cobaan yang dihadapi sambil terus berusaha untuk menyampaikan kebenaran dan kebaikan terhadap lingkungan di sekitarnya, khususnya terhadap orangtua dan keluarga terdekat melalui lisan, tulisan maupun akhlak dan adab yang baik, santun dan tepat serta dilakukan dengan cara yang hikmah serta memohon pertolongan dan perlindungan kepada Allah Subhaanahu wa Ta'aala. 
2) Bagi Orangtua dan Masyarakat

Bagi orangtua dan masyarakat sekitar hendaknya tetap bersikap tenang dan tidak terburu-buru untuk memberikan suatu kesimpulan serta prasangka negatif terhadap muslimah yang mengambil keputusan untuk memakai cadar. Meskipun terjadi perselisihan di kalangan para ulama terkait wajibnya hukum cadar dalam Islam, namun ulama yang berpendapat bahwa hukum cadar itu tidak wajib tetap mengingatkan dan menekankan bahwa menutup wajah bagi muslimah adalah lebih utama (memiliki keutamaan) karena dengan sebab itu kehormatan seorang muslimah dapat terjaga dengan sebab dia akan dikenal sebagai wanita baik-baik dan tidak diganggu oleh lakilaki yang bukan mahram-nya.

Bahkan dalam sudut pandang psikologi, cadar merupakan busana yang melambangkan privacy di mana ketika ada pria non-mahram yang dirasa akan mengganggu privacy, muslimah yang mengambil keputusan untuk memakai cadar akan memakai cadar untuk menutup seluruh tubuh bahkan wajahnya. Namun ketika muslimah tersebut berada di tempat yang aman di antara sesama muslimah lainnya di dalam rumahnya, maka mereka tidak akan memakai penutup wajahnya.

Oleh karena itu, tidak ada salahnya mencoba memulai sebuah diskusi ringan atau sharing dari hati ke hati dengan cara yang baik dan tepat sebagai jalan terbukanya komunikasi sehingga masing-masing pihak dapat saling memahami dan menghargai. Dengan memahami hal ini, diharapkan kita semua dapat bersikap lebih bijak dan tepat terhadap muslimah yang mengambil keputusan untuk memakai cadar, dan demikian pula sebaliknya.

3) Bagi peneliti selanjutnya

Bagi peneliti-peneliti selanjutnya yang ingin mengangkat topik penelitian yang sejenis hendaklah berusaha untuk bersikap netral tanpa prasangka serta melakukan klarifikasi terhadap maksud dari jawaban atau pernyataan responden dan menambahkan informan yang tepat (yaitu seseorang yang sangat dekat dan mengetahui proses pengambilan keputusan yang dilakukan oleh muslimah semenjak belum memakai cadar hingga memutuskan untuk memakai cadar pada akhirnya) untuk menambah kredibilitas data dari hasil penelitian sehingga dapat terhindar dari bias.

\section{Daftar Pustaka}

Al-Fauzan, S. (2006). Panduan Fiqh Praktis bagi Wanita. Pekalongan: Pustaka Sumayyah

Al-Wadi'iyyah, U.A. (2002). Nasehatku untuk Kaum Wanita. Solo: Pustaka ArRayyan

Dermawan, R. (2006). Pengambilan Keputusan: Landasan Filosofis, Konsep dan Aplikasi. Bandung: Alfabeta

Suharnan. (2005). Psikologi Kognitif. Surabaya: Srikandi

Gitosudarmo, I. \& Sudita, I. N. (1997). Perilaku Keorganisasian Edisi Pertama. Yogyakarta:BPFEYogyakarta 